\title{
Analysis and Design of Electronic Audit Paperwork: Documentation from an Internal Audit Unit (Case Study: University of X)
}

\author{
Renaldi Purnayudha \\ Accounting Department, Faculty of Economics and Business \\ Universitas Indonesia \\ Salemba, Jakarta Pusat, Indonesia \\ renaldi@ecampus.ut.ac.id \\ Machmudin Eka Prasetya \\ Accounting Department, Faculty of Economics and Business \\ Universitas Indonesia \\ Salemba, Jakarta Pusat, Indonesia \\ machmudin.prasetya@yahoo.com
}

\begin{abstract}
This study analyzes the information systems needs of the Internal Audit unit at the University of $X$ for documenting audit paperwork and designing electronic audit paperwork documentation to be integrated into one database application. This electronic paperwork is to be designed using the Framework for the Application of System Thinking model. Documentation of audit paperwork is undertaken to collect documents during auditing that originate from any source and with any relation to the scope of the audit. Auditing work begins from with the planning, preliminary survey, evaluation of management control, substantive testing, reporting, and follow up of the audit results. The research method used is the qualitative method, with a single case study approach. Data were collected through observation, interviews, and examination of documents. The results of this study will help SPI units document their audit paperwork electronically and in an integrated way such that audit paperwork is complete and integrated.
\end{abstract}

Keywords-information system, Framework for the Application of System Thinking, FAST, electronic audit paperwork, internal control unit

\section{INTRODUCTION}

This study addresses the information systems needs of the internal audit unit (SPI) at the University of $\mathrm{X}$ for documenting audit paperwork and designing electronic audit paperwork documentation integrated with a database application. The current documentation system for audit paperwork in the SPI unit at the University of $\mathrm{X}$ remains manual and does not use a special, integrated application. This results in incomplete audit paperwork.

Government regulations created by the Ministry for State Apparatus Reforms (Kementrian Pendayagunaan Aparatur Negara) require audit paperwork to document all information obtained during an audit. This information describes all audit activities, including planning, preliminary surveys, evaluation of management control, substantive testing, audit reporting, and following up on audit results.

The documentation system for audit paperwork in the internal audit unit at the University of $X$ remains manual and is not the product of an integrated application. This results in incomplete paperwork, and control of documentation is weak.

There are large amounts of support data for the audit and the paperwork maintained by the SPI unit produced each year. Audit planning, audit work programs, audit data support implementation, updating applicable rules and procedures, audit reporting and providing supporting evidence and follow up for audit findings, and auditor assessment forms must all be documented. Control of audit paperwork documentation is weak when it is only performed manually and without the use of any special integrated applications.

Another issue is the limitations of personnel, but this problem can actually be solved by increasing the number of personnel. However, as the University of $X$, which is a state university and is staffed by civil servants, personnel cannot be added because all hiring must be with the approval of the Ministry of Research, Technology, and Higher Education. In addition, confidential audit paperwork can only be accessed by parties who are authorized by management. This means that the management of audit documentation can only be performed by the SPI unit.

Current technological advances allow this work to be done more easily, faster, more effectively, and more efficiently. Therefore, the University of $\mathrm{X}$ requires more effective and value-added electronic audit paperwork. Study in this area is vital because it will support the SPI unit at the University of $\mathrm{X}$ in adopting electronic documentation of audit paperwork and integrate it to improve the control of 
auditing and reduce risks and problems that have appeared there.

The study of audit paperwork that has been conducted so far has been limited to investigation of proper documentation of audit paperwork but has avoided discussing how to design an electronic audit paperwork information system.

The formulation of this research problem is as follows, in two parts.

1. How can the needs of the SPI unit at the University of $\mathrm{X}$ for an information system to support the performance of proper, effective, efficientand value-added documentation of audits be assessed?

2. How can an electronic audit documentation management documentation system be developed in an integrated database application?

This study adopts a qualitative descriptive method with a single case study approach; this approach is chosen because it addresses issues in depth and detail to obtain a solution to the problem. Case study analysis is used to describe problems and provide recommendations and solutions to them [2].

The development of information systems in this study was performed using the Framework for the Application of Systems Technique (FAST) method to analyze and design electronic audit work papers. This method has eight stages: Scope Definition, Problem Analysis, Requirements Analysis, Logical Design, Decision Analysis, Physical Design and Integration, Construction and Testing, and Installation and Delivery [3]. Of these eight stages, this study only uses four: Scope Definition, Problem Analysis, Requirements Analysis, and Logical Design.

This research outline consists of five parts: introduction, literature review, methods, findings and discussion, and conclusion.

\section{PREVIOUS RESEARCH}

Audit paperwork was studied by Asmalesh [4] ; that study explored the standards and procedures for all auditing activities, beginning with the planning, content, use, retention, and disposition of audit paperwork. It contributed the awareness that audit paperwork documentation plays an important role in quality control.

This study has a different object, resulting in a similar but slightly adjusted method. The need for quality paperwork is analyzed further to fit the explore the research object. The design and development of an electronic audit information system should begin with an analysis of needs.

\section{LITERATURE REVIEW}

Audit paperwork is made up of records held by the auditor, which detail audit procedures, tests used, all information obtained, and the conclusions. Among audit paperwork can be found audit programs, analyses, memoranda, representation confirmation letters, corporate documents, and lists or comments made or obtained by the auditor. The paperwork may include data stored on magnetic tape, on film, or in other media.

Many methods exist for developing information systems, including the System Development Lifecycle method, the Waterfall method, the Prototyping method, the Rapid Application Development method, the Spiral method, the Object-Oriented Technology method, and the FAST method.

To meet the need for the development of information systems, the FAST method is used here because of its ability to support rapid application development. FAST is also called agile modeling, and it was developed from a combination of reference and methodological best practices. Additionally, it supports other techniques, including structured systems analysis, information engineering, and object-oriented analysis and design [3]. The Whitten version of the FAST methodology used in this study goes through the following stages:

Scope Definition. Scope definition has two objectives: first, it determines whether the problem found is important, and if so, second, can it be used to determine the size and scope, vision, mission, constraints, participating parties, budgets, and schedules of the projects to be solved.

Problem Analysis. This stage explores the existing system and analyzes the problem in the context of a broader understanding to allow problems to be analyzed, while also analyzing opportunities and constraints.

Requirements Analysis. This establishes the business requirements to be met through the system offered.

Logical Design Phase. Here, the business requirements that the system must meet for data, processes, and displays that ensure the usability, reliability, completeness, performance, and quality that the system should offer are assessed.

\section{METHODS}

Qualitative description is used here with a single case study approach, and the SPI unit at the University of X is the unit of analysis. The case study approach is chosen because it addresses issues in depth and detail to obtain a solution to the problem. Data collection methods used are interviewing and observation techniques for primary data-related business processes of document management, along with review of audit work documents. Secondary data are obtained from literature review of published work on information systems, flow diagrams, and entity relationship diagram, as well as the rules and procedures applicable to the task and function of 
the research object, with reports from the object of research and their attachments.

The SPI unit at the University of $\mathrm{X}$ is the object of research. The University of $\mathrm{X}$ is a state university, founded on September 4, 1984, by President Soeharto through Keppres No. 41 of 1984. It is governed by the Regulation of the Minister of Research, Technology, and Higher Education of the Republic of Indonesia No. 16 of 2017 on the Organization and Administration of University X, and it is supported by the Ministry of Research, Technology, and Higher Education.

The University of $\mathrm{X}$ is responsible to the Minister of Research, Technology, and Higher Education. SPI performs non-academic supervisory functions for and on behalf of the rector of the university. To achieve the vision, mission, and objectives of the University of X and become a highly competitive institution of higher education and implement good corporate governance, the University of X established its SPI unit with Rector Decree (SK) of the University of X No .7522 / UN31 / KEP / 2011, dated September 26, 2011, on the Establishment of Organization of an Internal Control Unit (SPI).

The formation of the SPI is based on to Government Regulation no. 60 of 2008, on a Government Internal Control System (SPIP) and Regulation No. 47 of 2011, on the Internal Supervision System (SPI) of the Ministry of National Education Environment. SPI has the duty and authority to perform the following:

- Determination of internal supervisory program policies for non-academic programs

- Internal supervision of non-academic education management

- Preparation of internal supervisory reports

- Provision of suggestions and/or considerations concerning improvements in the management of nonacademic activities to the rector on the basis of the results of internal controls, for further follow-up

Currently the SPI is staffed by a chairman, a secretary, three members (the employee of university), the administration manager of the administrative subdivision, assisted by three administrative staff, eight auditors, and one outsoursce employee.

To collect the data, the researchers interviewed the employees who documented audit paperwork, performed preliminary observations, and studied unit analysis documents related to audit paperwork. The researcher then performed an analysis and identified potential issues from data collection, using the Performance, Information, Economics, Efficiency, and Services (PIECES) framework, a stage of the FAST method, to derive expected improvements in the analysis.

\section{RESEARCH FINDINGS AND DISCUSSION}

To conduct an audit, the SPI must first draft an audit plan for its annual supervisory work program (PKPT), which is compiled in the previous year, using the criteria of setting objectives and types of audits, determining the amount of resources necessary (human, temporal, and budgetary) and the timing of the audit reports. Finance, human resources, and assets are all audited, and audits are conducted for all units in the University of $\mathrm{X}$, which has locations all over Indonesia.

With so many units being audited, the audit paperwork must be integrated and have value added (to be able to be used as a control for document completeness related to all audit stages). All stages of an audit must include planning, implementation, reporting, and follow-up audit results. These should be documented, not only by the SPI unit involved but several other units as well, especially the units to be audited, and they should be documented in audit work papers. The steps in the audit process are as follows:

\section{A. Audit Plan}

SPI should make a plan before it begins an assignment. This planning process is part of the creation of the PKPT, which is prepared in December of each year and drafted in relation to the products of the previous year's work for assigning the time of the next audit and the auditor to be assigned.

This preparatory work includes drafting a notice regarding the timing of the audit, the number of personnel to serve (and the positions of the team leader and members), and the data required. These data are divided into two groups that must be sent via email by SPI (softcopy), and data that must be prepared by the auditee when the audit team arrives. The data that must be sent to SPI via email include the following:

a) Planned activity funding

b) Recap of official travel for the current budget year and the two previous years

c) Bookkeeping status through the date that data are sent

d) Nominative list of all activities for the current fiscal year and the two previous years

e) Decision letter for the current budgetary year and the previous two years through the time of the nominative list submission

The data that must be prepared by the auditee for the audit team to conduct its field audits are the following:

a) Bookkeeping for the current fiscal year (general cash books, cash books, bank books, tax books, and other auxiliaries) of the current budget year and the two previous years

b) Current account for the current budgetary year and the two previous years

c) Work plan and budget auditee for the fiscal year and the two previous years

d) All responsibilities for the current budgetary year and the two previous years 
e) All reports on the implementation of activities for the current budgetary year and the two previous years

f) Documents for socialization and promotion, the orientation and socialization of new students, tutorials/practice, exams, and the graduation ceremony, as well as documents on the procurement of goods and services within the current budget and two previous years

g) Other documents to support the implementation of the audit, as required by the audit team.

A notification letter is emailed to the unit to be audited and the auditor assigned. In practice, audits are not always performed on time or in accordance with the established PKPT because the SPI does not provide the schedule for audit implementation to auditee or auditor much before the day it begins. SPI informs the auditee and auditor either two or three weeks before execution, so that if the auditor chosen is performing other duties, the audit experiences delay if the auditor is not replaced, which is very difficult. Furthermore, the if the auditee responds that the timing of the audit notification is too near to the implementation day, this may result in the postponement of the audit if the auditee has an activity agenda that would make the management of the audit unmanageable.

The TU staff completes the audit team's assignment, as assigned by the SPI chairman and approved by the rector. The assignment letter contains the name of the auditor to be assigned, his or her function in the audit team, the timing of the audit, and its scope. A letter of duty, signed by the rector, is then sent to the unit to be audited and the auditor to be assigned.

\section{B. Audit Implementation}

The audit team that conducts the audit usually consists of three people (a leader and two team members), and they are assigned for a seven-day period. The following audit procedures should be performed by the audit team:

\section{1) Desk Audit}

This is conducted to seek evidence of activities that may be incompatible with applicable rules and procedures (the potential audit objective). The audit team must master the auditee's business processes to determine the potential audit objective. This is carried out using data provided by the auditee via email and also using the results of previous audits and applicable regulations. In this part of their work, the audit team produces a preliminary survey report so that it can identify and assess the risks in auditee activities. Then, the team will selects those activities that pose the greatest risk for the audit sample.

\section{2) Field Audit}

After the team establishes the auditee activities through a preliminary survey, the team leader creates an audit program (PKA) and assesses the management control system used by the auditee, using an existing form. Then, the team conducts a series of internal control tests to determine the control risks, conducting limited research, involving document sampling, obtaining receipt evidence, and examining supporting evidence of compliance, as well as establishing tentative audit objectives (TAO). The audit team then performs further tests on the TAO, using physical examination, and it examines auditee activity through interviews, confirmation, or other auditing techniques.

Further test results obtained by the audit team can then become the basis for whether the auditee is conducting itself adequately in accordance with existing criteria. Results that deviate from or do not meet the criteria are then defined as findings, corroborated with supporting evidence, accompanied by conclusions on their causes and effects and the resulting recommendations.

Audit findings, causes, consequences, criteria violated, and recommendations are all set forth in the field audit paperwork (KKA), based on the pre-established PKA. The KKA is then reviewed by the team leader to determine whether the evidence strongly supports the findings. If it is not supported by strong findings, the team must obtain other supporting evidence.

After it is finalized by the audit team, the paperwork is then presented to the auditee at closing, and the auditee is given an opportunity to respond to the findings and draft a corrective plan as per the recommendations and timing of the settlement. Once the findings are agreed upon, the KKA is signed by the audit team, the head of the auditee unit, and the party responsible for the findings. The original KKA is taken by the audit team, and a copy is kept by the auditee.

\section{Reporting}

The approved audit results are presented to the SPI chair and the remainder of the SPI. Following this, the team leader creates an audit result report, which contains a description of the state of the auditee, an explanation of the findings, the findings that will be followed up on or the findings that have been followed up on in the field, the corrective action plan derived from the findings, and the plan made for the followup improvement of the findings, the results of the management control system assessment, the response of the auditee to the audit team, and the assessment created by the audit team itself.

After the audit process was determined, the researchers analyzed the system using the FAST method, passing through the following stages:

\section{1) Scope Definition}

The scope determination of the existing problem is performed through the establishing the feasibility of the scope. To test this, the PIECES framework must be used [3]. Table I presents current problems and expected improvements determined by observation and interviews conducted with several sources. 
TABLE I.

PIECES

\begin{tabular}{|c|c|c|}
\hline No. & Problem & Solution \\
\hline \multicolumn{3}{|c|}{ Performance } \\
\hline 1. & $\begin{array}{l}\text { PKPT is done manually, by requesting that the auditors in the SPI unit } \\
\text { collect auditees that have been audited in the previous year, the number } \\
\text { of findings, and any follow-up that has been done. }\end{array}$ & $\begin{array}{l}\text { Audited unit databases to create PKPT would allow this to be done more } \\
\text { quickly and precisely. }\end{array}$ \\
\hline 2. & $\begin{array}{l}\text { The audit team is made up of auditors who can perform the task on the } \\
\text { given schedule, not those who have the competencies, skills, and } \\
\text { experience to complement each other. }\end{array}$ & $\begin{array}{l}\text { The information system can be supplemented by auditor recapitulation, } \\
\text { obtained from the audit team's assessment form by the team leader and } \\
\text { vice versa, and the audit team's assessment of the audit to allow an } \\
\text { auditor's performance to be reviewed so that an upcoming audit work } \\
\text { program can be created and teams can be created and assigned using the } \\
\text { competencies and expertise the personnel have to make a } \\
\text { complementary group. }\end{array}$ \\
\hline 3. & $\begin{array}{l}\text { Supporting data for the performance of auditors in the form of rules and } \\
\text { procedures both of rules issued by the government and internal rules, } \\
\text { procedures, policy are not renewed because the KKA documentation is } \\
\text { not integrated. }\end{array}$ & $\begin{array}{l}\text { A database of applicable rules and procedures and policies that can be } \\
\text { updated by the person in charge of the SPI. }\end{array}$ \\
\hline \multicolumn{3}{|c|}{ Information } \\
\hline 1. & $\begin{array}{l}\text { Audit implementation is not always accurate or in accordance with the } \\
\text { PKPT, which is because the SPI does not announce the auditing } \\
\text { schedule to the auditor or auditee much before the day of } \\
\text { implementation. }\end{array}$ & $\begin{array}{l}\text { The existence of information systems that can allow auditors and } \\
\text { auditees to see information related to the scheduling of audits. }\end{array}$ \\
\hline 2. & $\begin{array}{l}\text { Audit data support obtained from auditee by way of the nominative } \\
\text { submission of honorarium activities, nominative official travel, } \\
\text { accountability, and other factors, is not documented in an integrated } \\
\text { manner and does not allow for easy supporting of the implementation } \\
\text { of audits or for data support for the audit is experiencing renewal. }\end{array}$ & $\begin{array}{l}\text { A database providing auditing support data from audits that can be } \\
\text { uploaded by auditors to enable audits to be securely transferred and not } \\
\text { sent via email and to be updated if changes are made, which can be } \\
\text { monitored, so SPI will no longer need to request new data each time it } \\
\text { performs an audit due to the requirement to audit three years of data. }\end{array}$ \\
\hline 3. & $\begin{array}{l}\text { The preparation of audit working papers containing the condition of the } \\
\text { findings, the criteria violated, and the causes and effects, as supported } \\
\text { by evidence, are done manually by the team, inhibiting the tiered } \\
\text { review made by the team leader and the chairman of the SPI }\end{array}$ & $\begin{array}{l}\text { An information system that would allow easy preparation of KKA, } \\
\text { accompanied by supporting evidence and could make it easier to do } \\
\text { reviews because making KKA can be seen in real-time by the reviewer. }\end{array}$ \\
\hline \multicolumn{3}{|c|}{ Economics } \\
\hline 1. & $\begin{array}{l}\text { The costs related to the preparation and the mandatory doubling of } \\
\text { audit reports, the requests for support data from auditees that are not } \\
\text { submitted before the audit, and the follow-up plan that goes beyond the } \\
\text { limit of the completion date plan. }\end{array}$ & $\begin{array}{l}\text { An information system that would allow auditors and auditees to access } \\
\text { audit reports related to their assignment. }\end{array}$ \\
\hline 2. & $\begin{array}{l}\text { Coordination with the auditee through telephone audits that must be } \\
\text { continuously performed, related to requests for supporting data audits } \\
\text { from auditees that are not sent until close to the time of the audit. }\end{array}$ & $\begin{array}{l}\text { An information system and databases that can upload needed data for } \\
\text { audit support. }\end{array}$ \\
\hline 3. & $\begin{array}{l}\text { Follow-up with the auditee regarding the follow-up plan when it has } \\
\text { exceeded its completion date is done by telephone, and information on } \\
\text { follow-up is not provided to the SPI chairman }\end{array}$ & $\begin{array}{l}\text { An information system that can make follow-up information on audits } \\
\text { easy to find and to track plans that have not been acted upon. }\end{array}$ \\
\hline \multicolumn{3}{|c|}{ Control } \\
\hline 1. & $\begin{array}{l}\text { Paperwork is created manually and is not integrated, meaning that it is } \\
\text { at risk of being scattered, lost, and read by parties without wide } \\
\text { authority }\end{array}$ & A secure information system that can be accessed remotely. \\
\hline 2. & $\begin{array}{l}\text { Documented worksheets are incomplete. During the planning stage of } \\
\text { an audit, a notification letter is sent to the unit to be audited, and the } \\
\text { letter of audit assignment that is part of the assignment belongs with the } \\
\text { audit documents but is stored with and managed by the administrative } \\
\text { division of the SPI unit }\end{array}$ & An information system that can integrate all documents. \\
\hline 3. & $\begin{array}{l}\text { Audit worksheets are not equipped with audit work programs or audit } \\
\text { reports, which shows the lack of control over the completeness of the } \\
\text { audit work papers. }\end{array}$ & An information system that can integrate all documents. \\
\hline \multicolumn{3}{|c|}{ Efficiency } \\
\hline 1. & $\begin{array}{l}\text { Supporting audit data in the form of rules, procedures, and supporting } \\
\text { data, sourced from auditing, are not integrated, and this complicates the } \\
\text { auditor's task when an audit is being conducted in the field, as the } \\
\text { auditor must communicate by telephone or mail with someone with } \\
\text { access to the related rules, which hampers audit implementation. }\end{array}$ & Database providing audit support data. \\
\hline 2. & $\begin{array}{l}\text { Unequal human resources in the SPI unit who perform document } \\
\text { management with a number of units that are auditees. }\end{array}$ & $\begin{array}{l}\text { The existence of systems that facilitate the management despite the } \\
\text { limitations of human resources. }\end{array}$ \\
\hline \multicolumn{3}{|c|}{ Services } \\
\hline 1. & $\begin{array}{l}\text { The audit team often finds it difficult to determine what criteria are } \\
\text { violated due to the non-integration of audit work papers. }\end{array}$ & Systems that integrate all audit support documents. \\
\hline 2. & $\begin{array}{l}\text { Follow-up improvements to audit findings are often delayed or do not } \\
\text { meet projected completion dates. }\end{array}$ & $\begin{array}{l}\text { The PIC of the auditee in the SPI unit and associated audits can look } \\
\text { over audit worksheets wo see what has not been performed by the } \\
\text { projected date of their completion. }\end{array}$ \\
\hline
\end{tabular}




\section{2) Problem Analysis}

In the problem analysis of this issue, the problems that occur are analyzed and discussed further, with an explanation provided for the causes, effects, and solutions offered so that the problem can be solved. This analysis is done to gain an understanding of the problems in the current business process. These problems and their effects and solutions are given in Table 2 below:

TABLE II. PROBLEM ANALYSIS

\begin{tabular}{|c|c|c|c|}
\hline No. & Problems & Consequences & Solution \\
\hline \multicolumn{4}{|c|}{ Planning } \\
\hline 1. & $\begin{array}{l}\text { The PKPT is still performed manually using } \\
\text { data that has been audited in the previous } \\
\text { year, the number of findings, and completed } \\
\text { follow-up. }\end{array}$ & $\begin{array}{l}\text { The timing of PKPT preparation is } \\
\text { inhibited, and inaccurate data are created } \\
\text { manually by the auditor in charge of the SPI } \\
\text { Unit. }\end{array}$ & $\begin{array}{l}\text { Electronic audit paperwork provides an audited } \\
\text { database of previously audited units to make PKPT } \\
\text { work faster and more precisely. }\end{array}$ \\
\hline 2. & $\begin{array}{l}\text { No announcement of the schedule of audit } \\
\text { implementation to auditors or auditees until } \\
\text { shortly before the day of implementation. }\end{array}$ & $\begin{array}{l}\text { Not all planned audit schedules are } \\
\text { conducted according to the timing of } \\
\text { implementation (forwarded or postponed). }\end{array}$ & $\begin{array}{l}\text { Electronic audit paperwork providing information to } \\
\text { auditors and auditees is related to the timing of the } \\
\text { audit, which is conducted only with the information } \\
\text { that the auditor and per auditee concerned exchange. }\end{array}$ \\
\hline 3. & $\begin{array}{l}\text { The team of auditors sent for auditing is not } \\
\text { chosen for mutually complementing } \\
\text { competencies, expertise, and experience. }\end{array}$ & $\begin{array}{l}\text { In certain teams, if the auditors involved do } \\
\text { not have the skills, competencies, or } \\
\text { appropriate experience, the audit results are } \\
\text { not ideal, and the team members cannot } \\
\text { complement each other's skills. }\end{array}$ & $\begin{array}{l}\text { Electronic audit paperwork that provides auditor- } \\
\text { valuation recapitulation information from performance } \\
\text { in audits as assessed by the team leader and vice versa, } \\
\text { along with information on the auditing team's } \\
\text { assessment of the audits, allowing the auditor's } \\
\text { performance to be reviewed and to enable upcoming } \\
\text { audit work programs to let teams be assigned in } \\
\text { relation to the competence and the expertise of its } \\
\text { personnel can complement each other. }\end{array}$ \\
\hline 4. & $\begin{array}{l}\text { SPTA should be part of audit paperwork, } \\
\text { but is stored and managed by the } \\
\text { administrative unit. }\end{array}$ & The audit paperwork is incomplete. & $\begin{array}{l}\text { Electronic audit paperwork that can integrate all } \\
\text { documents. }\end{array}$ \\
\hline 5. & $\begin{array}{l}\text { Auditor support for audits submitted } \\
\text { through the nominative submission of } \\
\text { activity fees, nominative official travel, } \\
\text { accountability, and so on, is not } \\
\text { documented in an integrated manner or } \\
\text { when the supporting data of the audit is } \\
\text { renewed. }\end{array}$ & $\begin{array}{l}\text { Desk audits cannot be performed, and the } \\
\text { implementation of audits is not supported. }\end{array}$ & $\begin{array}{l}\text { Electronic audit paperwork that provides a database of } \\
\text { from audits that auditors upload, such that } \\
\text { communication does not need to be via email and so } \\
\text { updates can be made if changes occur during can be } \\
\text { monitoring, so SPI will no longer need to request old } \\
\text { data again for each audit. }\end{array}$ \\
\hline 6. & $\begin{array}{l}\text { Coordination with telephone audits, which } \\
\text { must be continuously performed to follow } \\
\text { up requests for supporting data for audits } \\
\text { that are not announced until close to their } \\
\text { beginning. }\end{array}$ & $\begin{array}{l}\text { These cannot be performed as done desk } \\
\text { audits, and they hamper the implementation } \\
\text { of field audits. }\end{array}$ & $\begin{array}{l}\text { Electronic audit paperwork that provides information } \\
\text { and an auditing database where auditors can upload } \\
\text { data in response to audit support needs, and audits for } \\
\text { which supporting data has not been submitted can be } \\
\text { monitored. }\end{array}$ \\
\hline \multicolumn{4}{|c|}{ Implementation of Audit } \\
\hline 1. & $\begin{array}{l}\text { Data used to support the performance of } \\
\text { auditors in the form of rules and } \\
\text { procedures, meaning both rules issued by } \\
\text { the government and internal rules and } \\
\text { procedures and policies. }\end{array}$ & $\begin{array}{l}\text { Implementation of the audit is impeded and } \\
\text { the auditor cannot know for certain whether } \\
\text { the resulting findings violate the applicable } \\
\text { criteria. }\end{array}$ & $\begin{array}{l}\text { A database of applicable rules, procedures, and policies } \\
\text { that can be updated by the chair of the SPI. }\end{array}$ \\
\hline 2. & $\begin{array}{l}\text { Audit worksheets that are prepared do not } \\
\text { contain an audit work program for detailed } \\
\text { auditing in the field. }\end{array}$ & $\begin{array}{l}\text { The audit has an unclear purpose, and team } \\
\text { members receive no direction or guidance } \\
\text { in conducting the audit. In addition, } \\
\text { controlling audit teams that do not make } \\
\text { PKA result in non-compliance } \\
\text { documentation and the audit cannot be } \\
\text { completed. }\end{array}$ & $\begin{array}{l}\text { Electronic audit paperwork containing a form for an } \\
\text { integrated audit work program. }\end{array}$ \\
\hline 3. & $\begin{array}{l}\text { Preparation of audit work papers on } \\
\text { detailed audit findings containing the } \\
\text { conditions of findings, violated criteria, and } \\
\text { cause and effect patterns supported by the } \\
\text { evidence of findings collected manually by } \\
\text { the audit team. }\end{array}$ & $\begin{array}{l}\text { Inhibits the tiered review made by the team } \\
\text { leader and SPI chairman. }\end{array}$ & $\begin{array}{l}\text { An electronic audit paperwork system can make it easy } \\
\text { to do reviews, as the KKA-making process can be } \\
\text { viewed in real-time. }\end{array}$ \\
\hline \multicolumn{4}{|c|}{ Reporting and Follow $U p$} \\
\hline 1. & $\begin{array}{l}\text { Not all teams produce findings, and } \\
\text { collected auditing reports show weak } \\
\text { control over the completeness of the } \\
\text { paperwork. }\end{array}$ & Work remains undocumented. & $\begin{array}{l}\text { Electronic audit paperwork that can integrate all } \\
\text { documents such that it provides an overview for audit } \\
\text { teams before they make their reports. }\end{array}$ \\
\hline 2. & $\begin{array}{l}\text { Follow-up on follow-up plans created } \\
\text { exceed plan limits for the completion date is } \\
\text { done via telephone, without records being } \\
\text { made. }\end{array}$ & $\begin{array}{l}\text { The actual follow-up conducted is invisible } \\
\text { to the SPI chairman. }\end{array}$ & $\begin{array}{l}\text { Electronic audit paperwork that integrates the results of } \\
\text { follow-up to audits can permit interested parties to } \\
\text { keep track of follow-up for improving as a result of } \\
\text { audit findings. }\end{array}$ \\
\hline
\end{tabular}




\section{3) Requirement Analysis}

Once the problems have been outlined, the next step is to analyze the needs of the users of the new documentation system, based on the problems listed. Electronic paperwork is expected to support the SPI unit in managing and documenting audit paperwork so that documentation can be done effectively, efficiently, and with ease. The above description of problems lead to the necessity for the electronic audit paperwork to have the following features:

1. It should be able to provide a database of previously audited unit recapitulations to speed PKPT and make it more accurate.

2. Electronic audit paperwork should provide information to the auditors and auditees related to the audit timing.

3. The electronic audit paperwork should be able to provide the recapitulation information from the auditor obtained from audit team members' assessments and that of the team leader, as well as the other way around, and the auditing team's assessment of the audits such that the auditor's performance can be reviewed and to create an

\section{4) Logical Design}

At this stage, the user's need for electronic audit paperwork is transformed into a model. Modeling this system facilitates system users, system analysts, system designers, and system builders. System modeling illustrates aspects of the problem that are within the scope of the project and aspects that are outside the scope, in two stages.

The first process model (a technique used to organize and document the structure and flow of data through the system and the process or logic, policies, and procedures to be carried out by the system) was created with a data flow diagram (DFD), which is a method that describes the flow of data through a system, along with the system's response to the data flow.

The second is a data model, is a technique for defining and explaining business requirements for a database. The upcoming audit work program so that the competence and expertise of the personnel of the assigned team can be complemented by each other.

4. Electronic audit paperwork should integrate all planning-related documents (audit notices, assignment letters, and audit work programs), implementation (supporting data), and reporting and follow-up of audit results. These should only be accessible by users who have been issued an authorized user id and password to ensure that the materials are supervised only by auditing teams that have not provided documents relating to their obligations.

5. The electronic audit paperwork should produce a database of audit support data that can be uploaded, so that audits do not need to be sent via email and can be updated when changes arise that can be monitored, freeing SPI from requesting old data anew for each audit. Electronic audit paperwork should facilitate review because the process of making KKA can be viewed in real-time by the reviewer.

model used in data modeling is the entity relationship diagram, which describes data in the entity and the relationship terminology (relationship).

\section{MODELING PROCESSES}

\section{A. Functional Decomposition Diagram}

A functional decomposition diagram (FDD) is made to enable the knowledge of the processes that occur in electronic audit paperwork to allow it to be more easily understood and to describe the components in separate systems and subsystems. An FDD shows the hierarchy of the structure of a system to see the sequence of processes. FDD occupies an early stage in the construction of a flowchart. From the FDD, a context data flow diagram and DFD can be made. The following is an FDD for electronic auditing paperwork. 


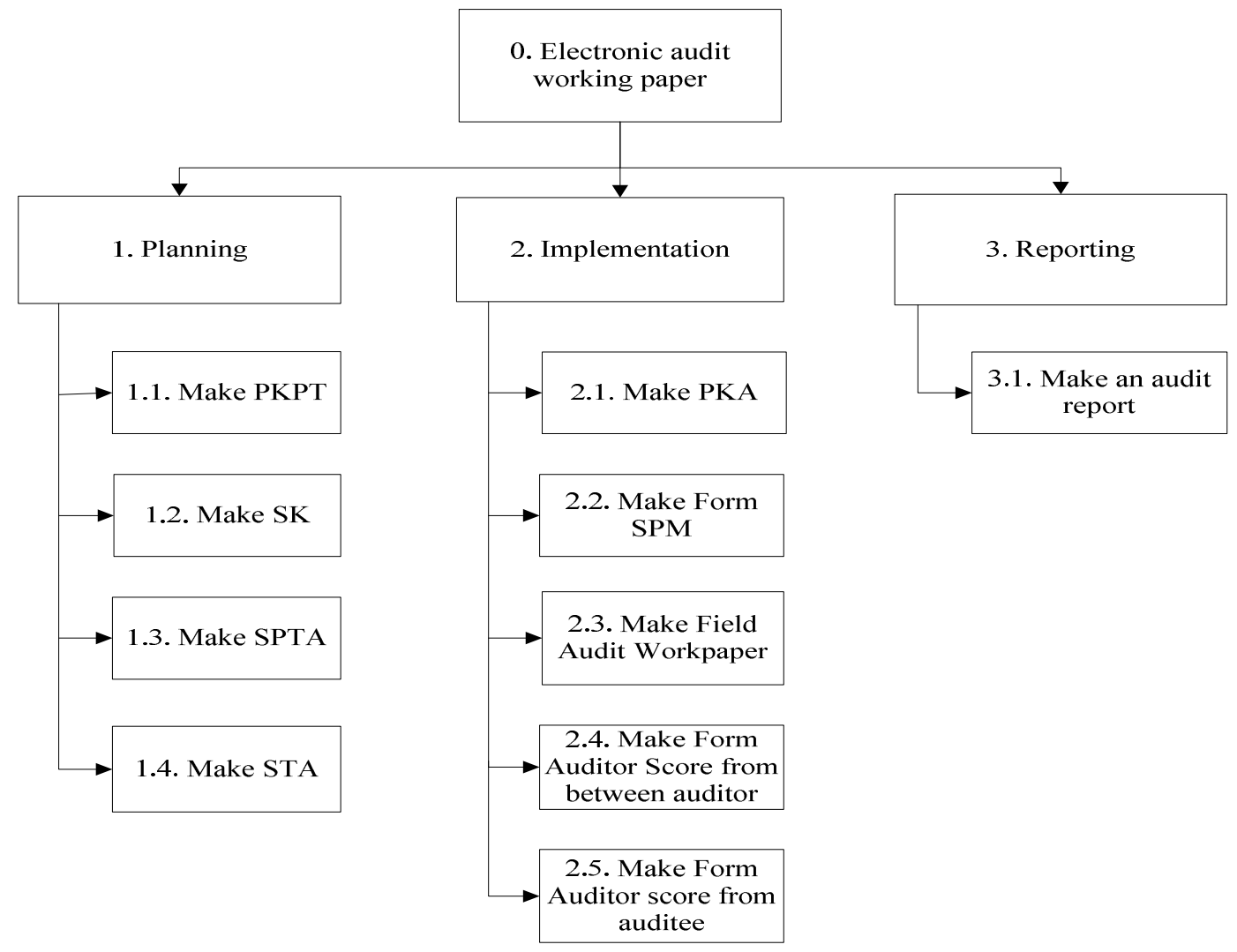

Fig. 1. FDD for electronic auditing paperwork

\section{1) Context Data Flow Diagram}

A context diagram is a DFD whose highest level describes the relationship between the system as a large process with the environment outside of that system. The first stage in creating a context diagram is determining the external agents or data stores that are part of electronic audit work papers, as will be explained below: the external agents here are outside parties both human and organizational, along with other systems related to the system.

TABLE III. LIST OF EXTERNAL AgENTS

\begin{tabular}{|l|l|l|}
\hline No. & \multicolumn{1}{|c|}{ External Agents } & \multicolumn{1}{c|}{ Description } \\
\hline 1. & Rector & $\begin{array}{l}\text { Official head for University of X, appointed by the Ministry of } \\
\text { Research, Technology and Higher Education, who determines the } \\
\text { university policy. }\end{array}$ \\
\hline 2. & Chair of SPI & $\begin{array}{l}\text { Officials who lead the SPI unit in determining the policy for } \\
\text { internal supervisory programs that are not academic and who } \\
\text { supervise the management of non-academic education. }\end{array}$ \\
\hline 3. & Secretary of SPI & $\begin{array}{l}\text { Officials who assist the SPI Chair in coordinating support for } \\
\text { supervision implementation. }\end{array}$ \\
\hline 4. & PIC of Administration (PJA TU) & $\begin{array}{l}\text { Echelon III Officer responsible for organizing administrative and } \\
\text { financial affairs, staffing, assets, and filing. }\end{array}$ \\
\hline 5. & PIC of Auditee (PJ) & Auditor assigned to the SPI unit. \\
\hline 6. & Lead & Team assigned to lead the team in an audit assignment. \\
\hline 7. & Team Member & $\begin{array}{l}\text { Team assigned under the leadership of the team leader in an audit } \\
\text { assignment. }\end{array}$ \\
\hline 8. & Auditee & Unit auditing within the work environment of the University of X \\
\hline
\end{tabular}

The next step after the external agents are determined is to create a context DFD. This illustrates aspects of the problems that are within the scope of the project and aspects that are outside its scope. The following is a context diagram for electronic audit paperwork, illustrated in Figure 2. 


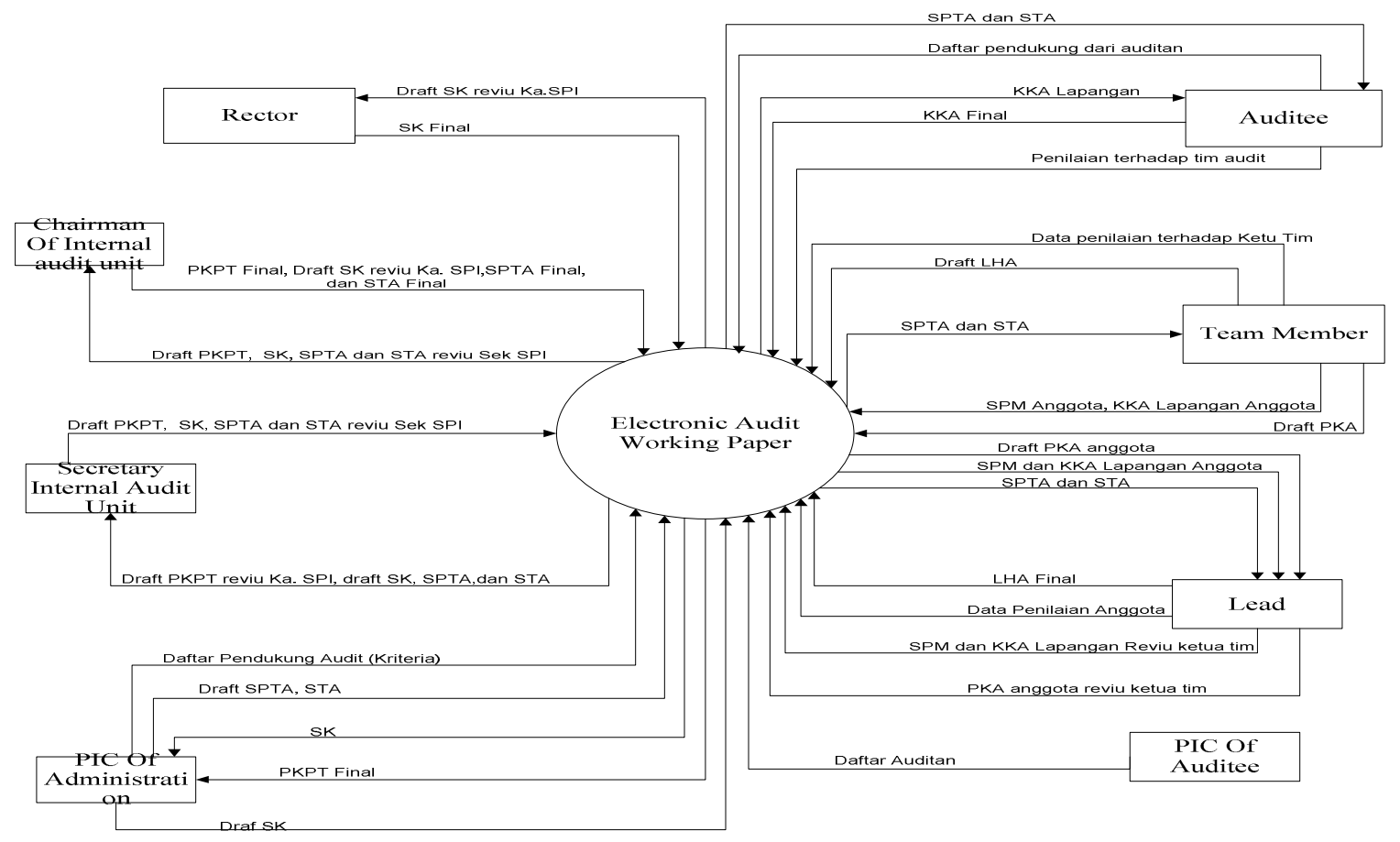

Fig. 2. Context Diagram 


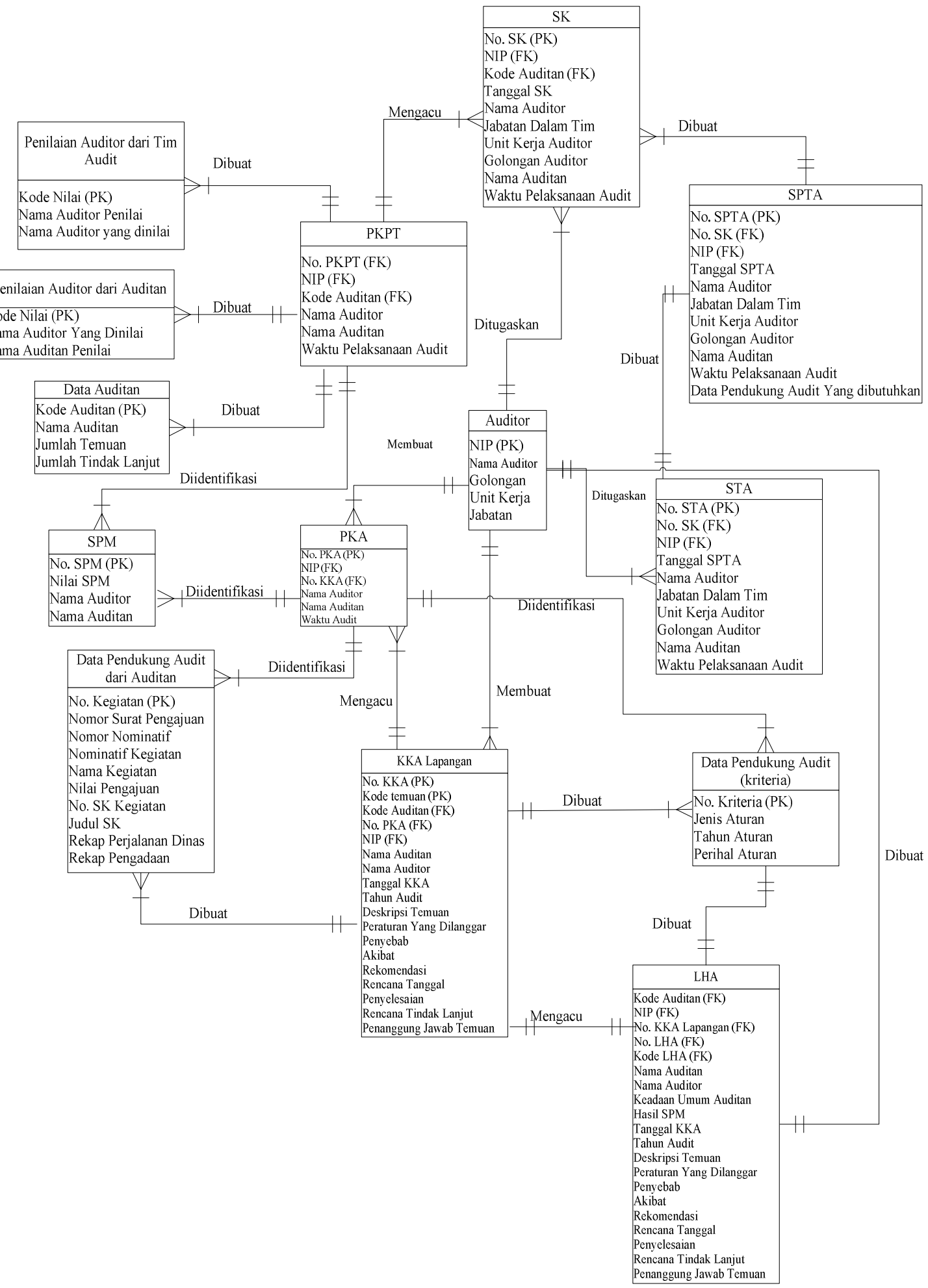

Fig 3. Attributed Data Model 


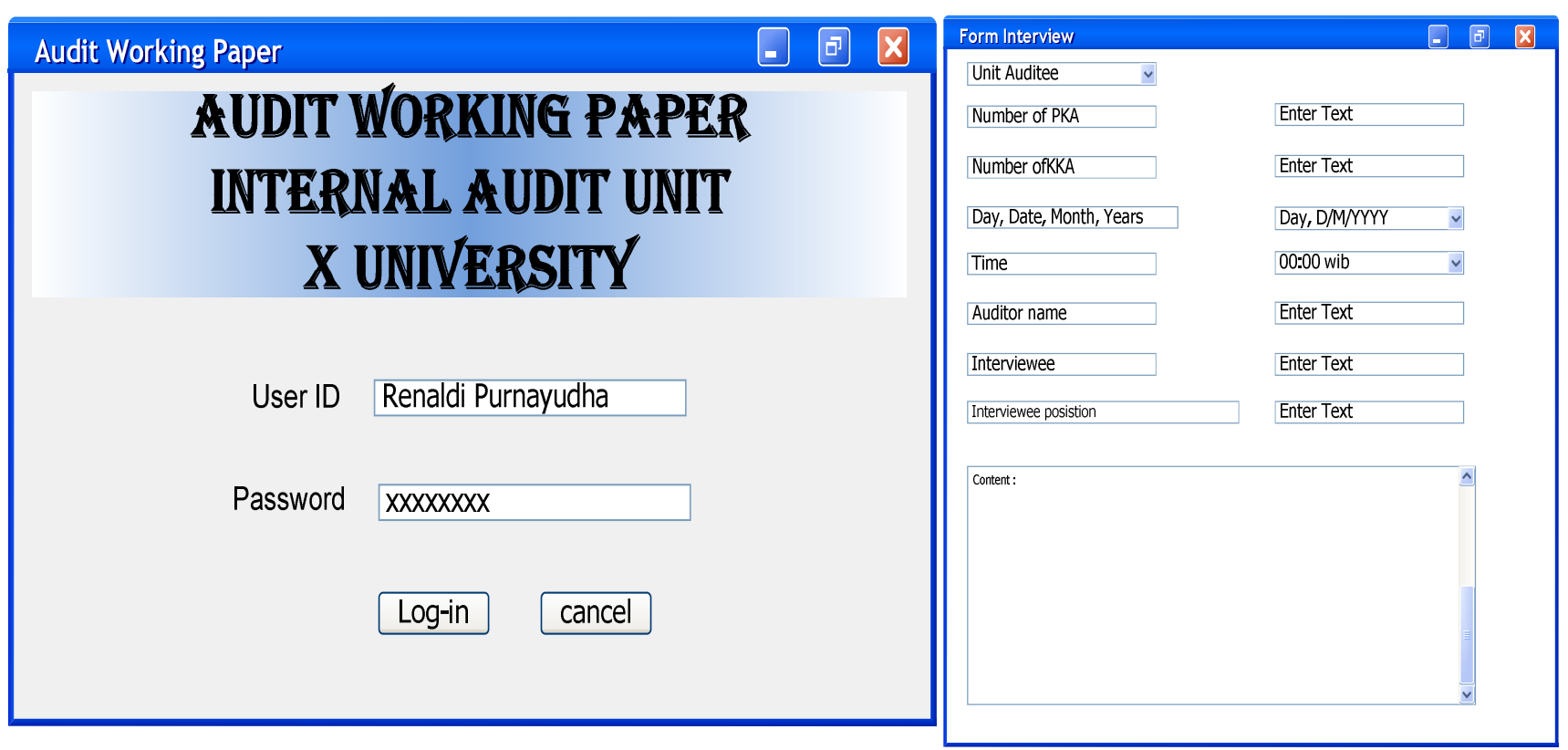

Fig 4.User Interface

\section{CONCLUSION}

Supervision is the main task of the SPI. There are several features of this supervision, including process planning, audit implementation process, and audit reporting process. This entire process should be well documented in the audit work papers. At present, the documentation is still done manually and is not integrated into one application, such that there is limited control over the entirety of the documentation. Due to the confidential nature of the audits, access to the documentation is limited to only those authorized by management.

The development of technology has allowed all parties to do all kinds of work and to perform tasks and functions more easily. Thus, the problem of audit documentation can be overcome, leading to a development of information systems in the form of electronic audit paperwork that can be used more easily and effectively and perform its function more precisely.

The design of electronic audit paperwork in this final paper uses the FAST method, $\mathrm{n}$ several stages: scope definition, problem analysis, requirement analysis, and logical design, producing data modeling.

This electronic audit paperwork may be a breakthrough because in addition to the integration of data and with database management support, it can also provide follow-up control of audit results and control the completeness of audit documents. The proposed process modeling picture has been complemented by the design of the database model, which can be used as the basis for the development of a more comprehensive database of activities in the SPI unit.
[1] Menteri Negara Pendayagunaan Aparatur Negara. (2008). Peraturan Menteri Negara Pendayagunaan Aparatur Negara Nomor PER/05/M.PAN/03/2008 Tentang Standar Audit Aparat Pengawasan Intern Pemerintah. Jakarta: Kementerian Negara Pendayagunaan Aparatur Negara.

[2] Sekaran, U., \& dan Bougie, R. (2010). Research method for business: A skill builcling approach (Edisi 5). New York: John Wiley.

[3] Whitten, J. L., \& dan Bentley, L. D. (2007). System analysis and design methods (7th Edition). New York: The McGrow-Hill Company.

[4] Asmalesh, A. (2014). Effective Role of Working Papers to Strengthen the Quality of Documents in Auditing-An Overview of Conceptual Study, IFSMRC AIJRM.

[5] Agoes, S. (2010). Auditing-Accounting Control by Kantor Akuntan Publik.

[6] Abdul K. (2002). Introduction of Information System, Andi: Yogyakarta.

[7] Arens, A. A., Elder, R. J, \& dan Beasley, M. S. (2012). Auditing and assurance services an integrated approach $\left(14^{\text {th }}\right.$ edition). New Jersey: Pearson International, 2012.

[8] Asosiasi Auditor Intern Pemerintah Indonesia (AAIPI). (2013). Standar Audit Intern Pemerintah Indonesia. Jakarta: Badan Pengawas Keuangan dan Pembangunan.

[9] Badan Pengawasan Keuangan dan Pembangunan (BPKP). (2018). Workshop PKA dan KKA.

[10] Ikatan Akuntan Indonesia (IAI). (2001). Standar Profesional Akuntan Publik

[11] Kusrini. (2007). Konsep dan Aplikasi Sistem Pendukung Keputusan. Penerbit Andi, Yogyakarta

[12] Limbong, B. (2013). Ekonomi Kerakyatan dan Nasionalisme Ekonomi, Margaretha Pustaka, Jakarta.

[13] Mcleod, Raymond Jr; P. George. (2010). Management Information System

(10th

Edition). Pearson Prentice Hall.

[14] Moeller, R. (2009). R. Brink's Modern Internal Auditing ( $7^{\text {th }}$ edition). New Jersey: John Wiley \& Sons, Inc.

\section{REFERENCES}


[15]Presiden Republik Indonesia. (2008). Peraturan Pemerintah No. 60 Tahun 2008 tentang Sistem Pengendalian Intern Pemerintah. Jakarta: Sekretariat Negara RI.

[16] Romney, M. B., \& dan Steinbart, P. J. (2012). Accounting Information Systems (12th Edition). Harlow: Pearson Education Limited.

[17] Sawyer \& Glen E. S. (2005). Sawyer's Internal Auditing, the new edition is 6th edition with new format.
[18] Turban, E., \& Linda V. (2012). Information technology for management, 8th Edition. John Wiley \& Sons, Asia.

[19] Ketua SPI. (2016). Laporan tahunan unit SPI 2016.

[20] The Institute of Internal Auditors. (2017). http://www.theiia.org

[21] Whitington, R., \& Fisbach, G. (2002). The new audit documentation requirements. Journal Of Accountancy Online. April 2002. 